VERSITA

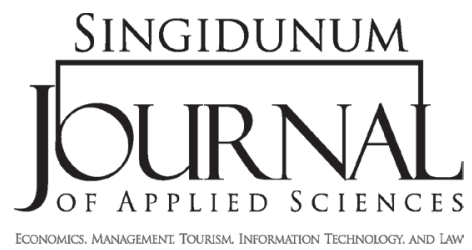

SINGIDUNUM JOURNAL 2013, 10 (2): 53-63

ISSN 2217-8090

UDK $316.77: 004 ; 314.151 .3-054.72(=871)(73)$

DOI: $10.5937 /$ sjas $10-4207$

Original paper/Originalni naučni rad

\title{
A STUDY OF HAITIAN IMMIGRANT'S ASSIMILATION TO WESTERN PRACTICES OF USING THE TELEPHONY AND INTERNET TECHNOLOGIES
}

\author{
Borivoje-Boris Đokić ${ }^{1,{ }^{*}}$, Rhonda Polak2, \\ Jeanette D. Francis ${ }^{3}$, Bahaudin G. Mujtaba ${ }^{4}$ \\ ${ }^{1}$ Keiser University Graduate School \\ 1900 West Commercial Boulevard, FL 33309, United States \\ ${ }^{2}$ N.A.B.A. Consulting \\ 2153 Nw 73rd Lane in Pompano Beach, Florida, United States \\ ${ }^{3}$ Lynn University, College of Business and Management \\ 3601 N Military Trail, Boca Raton, FL 33431, United States \\ ${ }^{4}$ Nova Southeastern University \\ 3301 College Ave, Fort Lauderdale, FL 33314, United States
}

\begin{abstract}
:
This study examines the relationship between the use of technology to stay connected with home country and culture while adapting and integrating into the host culture. Through a survey the authors probe into how Haitian immigrants living in South Florida with varying levels of contact with their home country acculturate into the receiving society, exploring an increasingly salient experience of contemporary global migrants. Immigration is the experience of acculturation by individuals and the emergence of culturally plural societies, where both immigrants and host country citizens can live together in a positive environment. In this study, we report our exploratory findings and insights from a survey conducted among Haitian immigrants in South Florida area, studying the relationship between the scope of their electronic communication, and their level of integration into the mainstream American culture. Considerable research has been devoted to the understanding of immigration, acculturation and adaptation of adults, but much less has addressed these phenomena among Haitian population in reference to the use of communication technologies to keep in touch with their loved ones overseas and being fully adapted to their host country at the same time, asserting both identities. In other words, to what extend Haitians who wish to have contact with American culture, while maintaining their cultural attributes do so through the Internet and telecommunication technologies.

The objective of this study is to explore the correlation between cultural integration process and the level of Internet and telephony technologies usage among Haitians living in South Florida. The Internet and telephones are a necessity becoming central for one's knowledge of environment, for the retention of one's social contacts but also for the organization of one's life. This is especially true for immigrants who often rely on their new and old social networks in order to adjust to the host country.
\end{abstract}


This study looks at five well understood measures or indicators of the acculturation process, namely language proficiency, language use, length of time in the host culture, age, and peer contact. It also looks at the preferences of Internet related tools to contact friends and relatives both in Haiti and the USA by email, text messaging, and social sites.

In our study, highly integrated Haitian immigrants are those who are young, have lived here for a long time, are proficient in Creole and English, speak to friends and relatives in both languages, and spend their free time with both Americans and other Haitians.

\section{Key words:}

cultural integration,

immigrant,

communication technologies,

Internet,

telephony technologies,

correlation.

\section{INTRODUCTION}

Unlike early twentieth century immigrants who could not communicate directly homeward, or easily develop connections in the host country, global diaspora dwellers now have a plethora of technological choices. With the advent of mobile telephony and Internet technologies to interconnect, share and communicate in virtual spaces, immigrants are finding it easier to expand their neighborhood connections, while at the same time reaching out to those family members and friends who remain in their home country. Time and geographical barriers are progressively fading, as access to people is just a click away. Indeed, the convenience, interactivity, flexibility and open-connectivity of these new medium create new avenues for enhancing the quality and quantity of communication.

In this study, we report our findings and insights from an exploratory survey conducted among Haitian immigrants in the Southeast region of the United States - South Florida area, studying the relationship between the scope of their electronic communication, and their level of acculturation to the mainstream American culture.

\section{PURPOSE OF THE STUDY}

The objective of this study is to explore the correlation between cultural integration process and the level of Internet and telephony technologies usage among Haitians living in South Florida. The Internet and telephones are a necessity becoming central for one's knowledge of environment, for the retention of one's social contacts but also for the organization of one's life. This is especially true for the immigrants who often rely on their new and old social networks in order to adjust to the host country. This study looks at five well understood measures or indicators of the acculturation process, namely, language proficiency, language use, length of time in the host culture, age, and peer contact. It also looks at the preferences of Internet related tools to contact friends and relatives both in Haiti and the USA by email, text messaging, and social sites.

Considerable research has been devoted to the understanding of immigration, acculturation and adaptation of adults, but much less has addressed these phenomena among Haitian population in reference to the use of communication technologies to keep in touch with their loved ones overseas and being fully adapted to their host country at the same time, asserting both identities. In other words, to what extend Haitians who wish to have contact with American culture, while maintaining their cultural attributes do so through the Internet and telecommunication technologies.

\section{PROBLEM AND ITS BACKGROUND}

\section{Are communication technologies a hindrance or help in immigrant acculturation?}

Research Question has two parts:

1. Is there a significant relationship between duration of residence in the United States of Haitian immigrants and their usage of electronic communication with family and friends in the United States and Haiti?

2. Does this relationship depend upon age.

The authors have defined five hypotheses:

Hypothesis 1

There is a positive relationship between duration of residence in the United States and the degree of usage of electronic communications with family and friends in the United States.

Hypothesis 2

There is a negative relationship between duration of residence in the United States and the degree of usage of electronic communications with family and friends in Haiti. 


\section{Hypothesis 3}

There is a positive relationship between age of residents in the United States and the degree of usage of electronic communications with family and friends in Haiti.

\section{Hypothesis 4}

There is a positive relationship between age of residents in the United States and the degree of usage of electronic communications with family and friends in Haiti.

\section{Hypothesis 5}

There is a positive relationship between age, duration and which electronic communication device is used to communicate with family and friends in the United States and Haiti.

\section{POPULATION}

The population consisted of the Haitian immigrants in South Florida. The sampling method used was convenience sampling. Sample consisted of the employees of South Florida universities that researchers had access to.

\section{Review of Literature}

Immigration is a worldwide trend, and in South Florida it is heavily influenced by Latinos and Caribbean immigrants, thus posing problems and opportunities for individuals and society as a whole. The Haitian diaspora in the United States - the largest concentration in any single country of Haitians abroad - is about 535,000 immigrants with more than $70 \%$ of them residing in Florida and New York (Terrazas, 2010). An outcome of immigration is the experience of acculturation by individuals and the emergence of culturally plural societies, where both immigrants and host country citizens can live together in a positive environment.

Transnational migrants of today have significantly different experiences from those who migrated during the $20^{\text {th }}$ century many change countries more than once, driven by job, educational and lifestyle opportunities. The importance of studying these new experiences and their meanings and implications cannot be overemphasized, as in the process of moving to a new host-culture involves behavioral, perceptual and attitudinal changes such as languages spoken, goods purchased, methods of communication, etc. In addition, migrants establish and maintain active and extensive social networks across shifting geo-political borders. These relationships tend to be sustained through regular contact by e-mail, chats, and telephone calls.

Acculturation is the process by which individuals adapt to cultural and psychological changes (Valencia and Johnson, 2008). Cultural changes are those related to a group's customs as well as its economic and political life. Psychological changes are those linked to an individual's attitude to the acculturation process, cultural identity, behavior, wellbeing and social skills.

Valencia and Johnson (2008) did an extensive analysis of the development of different acculturation theoretical models and measures over the past 2 decades in an effort to understand what happens to individuals who have lived in one culture and later on tried to adapt to a new culture. Their analysis of the literature has resulted in four major models, each one with their respective exponents and supporters:

The unilinear model assumes that the new immigrants would need to abandon their culture of origin in order to adapt to the new culture. The acculturation of the foreign-born and their children to the host society, as well as their socioeconomic mobility over time, are the key factors in the assimilation process (Iceland and Nelson, 2010). In countries, most immigrants tended to undergo a predictable process of identity loss or sacrifice followed by assimilation within their host countries, having left and cut off ties with their home countries behind for all practical purposes, as most immigrants never returned home (Gordon, 1964). Today, with the possibility of ongoing contact with the home country, this kind of closure and leaving behind does not occur, so the acculturation possibly takes longer, if it takes place at all.

The bi-dimensional model suggests that an individual can exhibit a high level of integration in both cultures; it is not essential for the individual to lose contact with one culture while adapting to another. Major proponents include Berry $(2003,2006)$ and Ramirez (1984).

The bilinear model, views the acculturation as a process in which changes occur both within the culture of origin as well as within the host culture, emphasizing the mutual interchange that occurs, while the orthogonal model proposes that identi- 
fication with any culture is independent of identification with any other culture. Any combination or pattern of cultural identification is possible, thus, a person may exhibit a single cultural identity, a bicultural identity, etc. (Beauvais and Oetting, 1990)

In this study we focus on the multicultural or bi-dimensional acculturation framework as examined by Berry $(2003,2006)$. In this framework two issues - degree of heritage preservation and degree of host-culture involvement - are crossed creating a four section space within which individuals may express how they are seeking to acculturate. This process is referred to as acculturation attitudes.

Considerable research has been devoted to the understanding of immigration, acculturation and adaptation of adults, but much less has addressed these phenomena among Haitian population in reference to use of communication technologies to keep in touch with their loved ones overseas and be integrated to their host country.

The study was guided by two core questions. First, we wanted to explore how Haitian immigrants live in their host-cultural settings (i.e. American culture). Here we want to gain insight into Haitian acculturation attitude, cultural identity, language proficiency, peer contact, family values, stress level and perceived discrimination correspond to the bidimensional view, as well as to describe ways they acculturate along demographic variables. Second we want to explore the correlation between acculturation process and the level of Internet and telephony technologies usage among Haitians living in the USA as they keep in touch with family and friends.

Individuals' link to their cultures of origin and to their receiving culture can be manifested in a number of ways, from dealing with preferences to the behavior they engage in. Acculturation attitudes or preferences for involvement were assessed through 4 questions related to preferences for the language chosen to view websites. For example "I prefer Creole websites serving Haitian users" or "I prefer websites in English serving all users". Two other questions examined the sense of belonging with either the American or Haitian way of life.

"Assimilation is the way when there is little interest in cultural maintenance combined with a preference for interacting with the larger society. Separation is the way when cultural maintenance is sought while avoiding involvement with others. Marginalization exists when neither cultural maintenance nor interaction with others is sought. Inte- gration is present when both cultural maintenance and involvement with large society are sought" (Barry, 2006).

Cultural Identity, operationalized by ethnic affirmation was assessed by three questions "Our children should be taught about our history and culture so that they feel pride and know who they really are" and "we should adapt to American society in order to earn a living but stay together as a group to preserve our culture and way of life", "Schools should help our children learn American ways of behavior and to become like American children in the neighborhood. Berry and Kalin (1995) assert that how one thinks of himself is also constructed along two dimensions: identification with one's heritage or ethno cultural group and identification with a larger or dominant society.

Language is examined through psychosocial domain by Valencia and Johnson (2008) and Berry (2006), through language proficiency and Bourhis, 1994) through language knowledge. Proficiency inquired about people abilities to understand, speak, read and write the ethnic language. Proficiency of the national language was assessed with the same questions, but with respect to the national language.

Language use refers to the extent to which individuals use either ethnic or national language when talking with their parents or their siblings and friends (Berry, 2003).

Peer contact assesses the frequency of interaction with peers from one's own ethnic group, or from the host culture group (Berry, 2003; Valencia and Johnson, 2008) assessed attitudes through the dimension of assessing attitude and behavior thought culture of origin and the host culture.

Psychological Adaptation looks into life satisfaction, stress levels (Jiali Yer), time living in the U.S.A, and the preference for neighborhoods with a larger proportion of residents who are from one's own culture. Questions such as "rate the level of stress in your life' and "How happy are you living in the U.S." were used.

Perceived Discrimination assesses what was assessed as perceived of feeling unacceptable because of one's ethnicity was measure with the question. "We will never have equal status with Americans; we will always be second class citizens."

Lee, Choi, Kim and Hong (2007) examined cultural profiles and post-adoption beliefs in the context of mobile Internet. They pointed out that the results of a large-scale online survey indicated 
that four cultural factors - uncertainty avoidance, individualism, contextuality and time perception have a significant influence on users' post-adoption perceptions of mobile Internet services. Ko, Roberts and Cho (2006) implied that there are significant differences between high-context and low-context cultures with regard to consumer motivation and interactivity as they conducted research gathering data from both U.S. and South Korean participants.

\section{RESULTS}

Data collection involved completion of a structured questionnaire. All participants were informed that the participation was voluntary, and that all responses were anonymous. The questionnaire assessed a wide range of variables related to acculturation and adaptation. Measures were either developed for the project or taken directly or with modifications from the existing scales.

Descriptive statistics shows that the use of particular electronic communications by Haitian immigrants varied significantly depending on the type of communication device. For the sampled population of 103 Haitian immigrants, the preferences for using the particular electronic modes of communication were evaluated using the data scored on the Likert Scale results for which "1" indicates the highest preference and " 5 " the lowest preference. One-tailed T-tests were used to judge statistically significant differences in mean Likert Scale scores at $\mathrm{p}=0.10$.

Cell phones either through voice communication (mean score of 1.81) or via text messaging (mean score of 1.97) were used to a significantly greater degree than all other communication modes. Social media such as Facebook (mean score of 2.76) and Twitter (2.87) were the next most frequently used communication modes. Skype (mean score of 3.29) and e-mail (mean score of 3.34) were used to a significantly less degree than the all other modes of electronic communication.

We relied upon the data set for individuals between 15 and 35 years old to evaluate trends in the use and type of electronic communications with residence time in the United States. We chose this group in order to have a common age group with representatives in all residence categories. In particular, the most recently arrived immigrants (those that have been in the U.S. for less than 5 years) were all within this age range. This stratification of our data by age yielded 49 people.
The results show that there were significant increases in the use of certain types of communication with residence time in the United States. This positive relationship was seen for cell phones, twitter, and for the use of Skype.

The results also show that there was a significant decrease in the use of electronic communications with family and friends in Haiti with increasing residence time for all modes of electronic communication.

In order to further explore the possible influence of residence time on the use of various modes of communication, we compared two groups within the 15-35 year old population. The first group involved recent immigrants (less than 5 years in the U.S.) and the second group involved longer-term residents (in the U.S. for 15 to 25 years). From the Likert Scale data, we derived average scores regarding the use of various electronic communication modes. We compared these groups using Student T-Test and chose a $p$ Value of 0.1 for judging statistical significance (see Table 2).

The degree to which various modes of communication are used track with our earlier description. Cell phones (using voice or texting) were preferred over other communication modes.

Significant differences were observed between recent immigrants and those that have been here for over 15 years. As Table 2 shows, longer-term residents made significantly greater use of cell phones for voice communications. They also used Twitter and Skype to a significantly greater degree than recent immigrants to communicate with friends in the United States.

In comparison of recent immigrants and longer-term residents with respect to communicating to individuals in Haiti the results indicate that recent immigrants are communicating with friends and family in Haiti but to a less degree than they are within the United States. The results also show that longer-term residents have negligible electronic communication with individuals in Haiti. Taken together Tables 1, 2 and 3 reveal a shift in the usage of electronic communications over time and a shift away from communications with friends and relatives in Haiti.

Correlation analysis of the overall age and duration of the number of years in the USA supports the descriptive analysis findings.

Duration of the stay in the USA has relatively strong (.234), statistically significant, positive cor- 
relation with the usage of e-mail in the USA, and weak, statistically not significant, negative correlation with e-mail usage in Haiti. In addition, the relationship between the duration of the stay in the USA and the use of social networks in the USA and twitter social media preference to contact friends in Haiti has a weak negative correlation.

The overall age of the participants had a relatively strong (.236), statistically significant correlation with the usage of the e-mail to contact friends in the USA, as well as a negative strong $(-.474,-.522,-.575)$ statistically significant correlation with the usage of e-mail in Haiti, text preference to contact friends in Haiti by texting, and usage of twitter social media preference to contact friends in Haiti. The results of the SPSS procedures are given in the appendix B.

\section{DISCUSSION}

In this paper we use patterns of usage of electronic communications as one measure of acculturation for Haitian immigrants. We hypothesized that the usage of various modes of communication would increase with an increase in residence duration and that there would be a positive shift toward communication with friends and family in the United States and a decrease in such communication with family and friends in Haiti.

Our results showed that cell phones were the most utilized form of electronic communication and that there was an increase in the cell phone usage for voice calling with residence duration in the United States. We did not see a similar trend for text messaging. In fact, text messaging was used to a great extent by newly arrived immigrants and was their primary form of electronic communication. The use of Twitter and Skype also increased with an increase in residence duration, although these communication modes are utilized less frequently than cell phones.

Communication with friends and family in Haiti declined significantly over time for almost all modes of electronic communication. For individuals who had been in the U.S. for more than 15 years, the use of electronic communications to correspond with friends and family in Haiti was negligible.

\section{APPENDICES:}

\section{Appendix A:}

\begin{tabular}{lccc}
\hline Communication medium & $\begin{array}{c}\text { Recent immigrants } \\
(<5 \text { years in U.S. })\end{array}$ & $\begin{array}{c}\text { Longer-term residents } \\
(>15 \text { years in U.S. })\end{array}$ & P value \\
\hline Text messaging & 1.38 & 1.85 & 0.15 \\
\hline Mobile phone voice & 2.08 & 1.2 & $0.0003^{* *}$ \\
\hline e-mail & 2.85 & 2.9 & 0.91 \\
\hline Social media & 3.15 & 2.55 & 0.29 \\
\hline Twitter & 3.77 & 2.40 & $0.02 * *$ \\
\hline Skype & 5.00 & 4.20 & $0.02 * *$ \\
\hline
\end{tabular}

Table 1. Relationship between duration of residence in the United States and the degree of usage of electronic communications for younger individuals (15 to 35 years old). Significance indicated with "**".

\begin{tabular}{lll}
\hline \multicolumn{1}{c}{ Communication medium } & $\begin{array}{c}\text { Communications to friends and family } \\
\text { in U.S. }\end{array}$ & $\begin{array}{c}\text { Communications to friends and family } \\
\text { in Haiti }\end{array}$ \\
\hline Text messaging & 0.04 & $-0.53^{* *}$ \\
\hline Cell phone & $0.30^{* *}$ & $-0.50^{* *}$ \\
\hline e-mail & 0.06 & $-0.45^{* *}$ \\
\hline Social media (e.g., Facebook) & 0.22 & $-0.65^{* *}$ \\
\hline Twitter & $0.38^{* *}$ & $-0.58^{* *}$ \\
\hline Skype & $0.28^{* *}$ & $-0.29^{* *}$ \\
\hline
\end{tabular}

Table 2. Correlation between residence in U.S. and use of electronic communications to communicate with friends and family in the U.S. and Haiti. Sample size $=49$; correlation coefficients of 0.276 and higher are statistically significant at $p=0.05$ for two-tailed comparisons and are marked with "**”. Positive correlation values indicate that usage increases with residency while negative values indicate a decrease in usage. 


\begin{tabular}{lccc}
\hline Communication medium & $\begin{array}{c}\text { Recent immigrants } \\
(<5 \text { years in U.S. })\end{array}$ & $\begin{array}{c}\text { Longer-term residents } \\
(>15 \text { years in U.S. })\end{array}$ & P value \\
\hline Text messaging & 3.62 & 5 & $0.03^{* *}$ \\
\hline Mobile phone voice & 3.77 & 5 & $0.0004^{* *}$ \\
\hline e-mail & 3.92 & 5 & $0.03^{* *}$ \\
\hline Social media & 3.15 & 5 & $0.0007^{* *}$ \\
\hline Twitter & 3.62 & 5 & $0.004^{* *}$ \\
\hline Skype & 4.85 & 5 & 0.17 \\
\hline
\end{tabular}

Table 3. Relationship between duration of residents in the United States and the degree of usage of electronic communications with family or friends in Haiti. Significance indicated with "**".

\section{Appendix B:}

H1:

There is a positive relationship between duration of residence in the United States and the degree of usage of electronic communications with family and friends in the United States.

Q3 - duration of residence in the USA, Q4 - age, Q5 - e-mail usage in USA, Q7 - texting in the USA, Q9- access to social networks in the USA

Descriptive Statistics

\begin{tabular}{cccc}
\hline & Mean & Std. Deviation & $\mathrm{N}$ \\
\hline Q3 & 3.13 & 1.135 & 103 \\
\hline Q5 & 3.34 & 1.718 & 103 \\
\hline Q7 & 1.97 & 1.472 & 103 \\
\hline Q9 & 2.87 & 1.851 & 103 \\
\hline
\end{tabular}

\section{Correlations}

\begin{tabular}{|c|c|c|c|c|c|}
\hline & & Q3 & Q5 & Q7 & Q9 \\
\hline \multirow{3}{*}{ Q3 } & Pearson Correlation & 1 & $.234^{*}$ & .073 & -.184 \\
\hline & Sig. (2-tailed) & & .017 & .466 & .063 \\
\hline & $\mathrm{N}$ & 103 & 103 & 103 & 103 \\
\hline \multirow{3}{*}{ Q5 } & Pearson Correlation & $.234^{*}$ & 1 & $.229^{*}$ & $.208^{*}$ \\
\hline & Sig. (2-tailed) & .017 & & .020 & .035 \\
\hline & $\mathrm{N}$ & 103 & 103 & 103 & 103 \\
\hline \multirow{3}{*}{ Q7 } & Pearson Correlation & .073 & $.229^{*}$ & 1 & $.258^{* *}$ \\
\hline & Sig. (2-tailed) & .466 & .020 & & .009 \\
\hline & $\mathrm{N}$ & 103 & 103 & 103 & 103 \\
\hline \multirow{3}{*}{ Q9 } & Pearson Correlation & -.184 & $.208^{*}$ & $.258^{* *}$ & 1 \\
\hline & Sig. (2-tailed) & .063 & .035 & .009 & \\
\hline & $\mathrm{N}$ & 103 & 103 & 103 & 103 \\
\hline
\end{tabular}

*. Correlation is significant at the 0.05 level (2-tailed).

**. Correlation is significant at the 0.01 level (2-tailed). 
$\mathrm{H} 2$ :

Descriptive Statistics

\begin{tabular}{cccc}
\hline & Mean & Std. Deviation & $\mathrm{N}$ \\
\hline $\mathrm{Q} 3$ & 3.13 & 1.135 & 103 \\
\hline $\mathrm{Q} 5$ & 3.74 & 1.698 & 103 \\
\hline $\mathrm{Q} 8$ & 3.73 & 1.579 & 103 \\
\hline $\mathrm{Q} 10$ & 3.51 & 1.782 & 103 \\
\hline
\end{tabular}

\begin{tabular}{cccccc}
\multicolumn{7}{c}{ Correlations } \\
\hline \multirow{3}{*}{ Q3 } & Q3 & Q5 & Q8 & Q10 \\
\hline \multirow{3}{*}{ Q5 } & Pearson Correlation & 1 & -.130 & .173 & -.032 \\
\cline { 2 - 6 } & Sig. (2-tailed) & & .190 & .081 & .745 \\
\cline { 2 - 6 } & $\mathrm{N}$ & 103 & 103 & 103 & 103 \\
\cline { 2 - 6 } & Pearson Correlation & -.130 & 1 & $.577^{* *}$ & $.690^{* *}$ \\
\cline { 2 - 6 } & Sig. (2-tailed) & .190 & & .000 & .000 \\
\cline { 2 - 6 } Q8 & $\mathrm{N}$ & 103 & 103 & 103 & 103 \\
\cline { 2 - 6 } & Pearson Correlation & .173 & $.577^{* *}$ & 1 & $.754^{* *}$ \\
\cline { 2 - 6 } & Sig. (2-tailed) & .081 & .000 & & .000 \\
\cline { 2 - 6 } Q10 & $\mathrm{N}$ & 103 & 103 & 103 & 103 \\
\cline { 2 - 6 } & Pearson Correlation & -.032 & $.690^{* *}$ & $.754^{* *}$ & 1 \\
\cline { 2 - 6 } & Sig. (2-tailed) & .745 & .000 & .000 & \\
\cline { 2 - 6 } & $\mathrm{N}$ & 103 & 103 & 103 & 103 \\
\hline
\end{tabular}

**. Correlation is significant at the 0.01 level (2-tailed).

H3:

Descriptive Statistics

\begin{tabular}{cccc}
\hline & Mean & Std. Deviation & $\mathrm{N}$ \\
\hline $\mathrm{Q} 4$ & 2.67 & 1.464 & 101 \\
\hline $\mathrm{Q} 5$ & 3.34 & 1.718 & 103 \\
\hline $\mathrm{Q} 7$ & 1.97 & 1.472 & 103 \\
\hline Q9 & 2.87 & 1.851 & 103 \\
\hline
\end{tabular}

Correlations

\begin{tabular}{|c|c|c|c|c|c|}
\hline & & $\mathrm{Q} 4$ & Q5 & Q7 & Q9 \\
\hline \multirow{3}{*}{ Q4 } & Pearson Correlation & 1 & $.236^{*}$ & .100 & -.129 \\
\hline & Sig. (2-tailed) & & .018 & 319 & .198 \\
\hline & $\mathrm{N}$ & 101 & 101 & 101 & 101 \\
\hline \multirow{3}{*}{ Q5 } & Pearson Correlation & $.236^{*}$ & 1 & $.229^{*}$ & $.208^{*}$ \\
\hline & Sig. (2-tailed) & .018 & & .020 & .035 \\
\hline & $\mathrm{N}$ & 101 & 103 & 103 & 103 \\
\hline \multirow{3}{*}{ Q7 } & Pearson Correlation & .100 & $.229^{*}$ & 1 & $.258^{* *}$ \\
\hline & Sig. (2-tailed) & .319 & .020 & & .009 \\
\hline & $\mathrm{N}$ & 101 & 103 & 103 & 103 \\
\hline \multirow{3}{*}{ Q9 } & Pearson Correlation & -.129 & $.208^{*}$ & $.258^{* *}$ & 1 \\
\hline & Sig. (2-tailed) & 198 & .035 & .009 & \\
\hline & $\mathrm{N}$ & 101 & 103 & 103 & 103 \\
\hline
\end{tabular}

*. Correlation is significant at the 0.05 level (2-tailed).

H4:

**. Correlation is significant at the 0.01 level (2-tailed).

Descriptive Statistics

\begin{tabular}{cccc}
\hline & Mean & Std. Deviation & $\mathrm{N}$ \\
\hline $\mathrm{Q} 4$ & 2.67 & 1.464 & 101 \\
\hline $\mathrm{Q} 5$ & 3.74 & 1.698 & 103 \\
\hline $\mathrm{Q} 8$ & 3.73 & 1.579 & 103 \\
\hline $\mathrm{Q} 10$ & 3.51 & 1.782 & 103 \\
\hline
\end{tabular}




\begin{tabular}{|c|c|c|c|c|c|}
\hline \multicolumn{6}{|c|}{ Correlations } \\
\hline & & $\mathrm{Q} 4$ & Q5 & $\mathrm{Q} 8$ & Q10 \\
\hline \multirow{3}{*}{ Q4 } & Pearson Correlation & 1 & $-.474^{* *}$ & $-.522^{* *}$ & $-.575^{* *}$ \\
\hline & Sig. (2-tailed) & & .000 & .000 & .000 \\
\hline & $\mathrm{N}$ & 101 & 101 & 101 & 101 \\
\hline \multirow{3}{*}{ Q5 } & Pearson Correlation & $-.474^{* *}$ & 1 & $.577^{* *}$ & $.690^{* *}$ \\
\hline & Sig. (2-tailed) & .000 & & .000 & .000 \\
\hline & $\mathrm{N}$ & 101 & 103 & 103 & 103 \\
\hline \multirow{3}{*}{ Q8 } & Pearson Correlation & $-.522^{* *}$ & $.577^{* *}$ & 1 & $.754^{* *}$ \\
\hline & Sig. (2-tailed) & .000 & .000 & & .000 \\
\hline & $\mathrm{N}$ & 101 & 103 & 103 & 103 \\
\hline \multirow{3}{*}{ Q10 } & Pearson Correlation & $-.575^{* *}$ & $.690^{* *}$ & $.754^{* *}$ & 1 \\
\hline & Sig. (2-tailed) & .000 & .000 & .000 & \\
\hline & $\mathrm{N}$ & 101 & 103 & 103 & 103 \\
\hline
\end{tabular}

H5:

Descriptive Statistics

\begin{tabular}{cccc}
\hline & Mean & Std. Deviation & $\mathrm{N}$ \\
\hline Q3 & 3.13 & 1.135 & 103 \\
\hline Q4 & 2.67 & 1.464 & 101 \\
\hline Q5 & 3.34 & 1.718 & 103 \\
\hline Q5 & 3.74 & 1.698 & 103 \\
\hline Q7 & 1.97 & 1.472 & 103 \\
\hline Q8 & 3.73 & 1.579 & 103 \\
\hline Q9 & 2.87 & 1.851 & 103 \\
\hline Q10 & 3.51 & 1.782 & 103 \\
\hline
\end{tabular}

Correlations

\begin{tabular}{|c|c|c|c|c|c|c|c|c|c|}
\hline & & Q3 & $\mathrm{Q} 4$ & Q5 & Q5 & Q7 & $\mathrm{Q} 8$ & Q9 & Q10 \\
\hline \multirow{3}{*}{ Q3 } & Pearson Correlation & 1 & $.282^{* *}$ & $.234^{*}$ & -.130 & .073 & .173 & -.184 & -.032 \\
\hline & Sig. (2-tailed) & & .004 & .017 & .190 & .466 & .081 & .063 & .745 \\
\hline & $\mathrm{N}$ & 103 & 101 & 103 & 103 & 103 & 103 & 103 & 103 \\
\hline \multirow{3}{*}{ Q4 } & Pearson Correlation & $.282^{* *}$ & 1 & $236^{*}$ & $-.474^{* *}$ & .100 & $-.522^{* *}$ & -.129 & $-.575^{* *}$ \\
\hline & Sig. (2-tailed) & .004 & & .018 & .000 & .319 & .000 & .198 & .000 \\
\hline & $\mathrm{N}$ & 101 & 101 & 101 & 101 & 101 & 101 & 101 & 101 \\
\hline \multirow{3}{*}{ Q5 } & Pearson Correlation & $.234^{*}$ & $236^{*}$ & 1 & $-.265^{* *}$ & $.229^{*}$ & .078 & $.208^{*}$ & $-.208^{*}$ \\
\hline & Sig. (2-tailed) & .017 & .018 & & .007 & .020 & .435 & .035 & .035 \\
\hline & $\mathrm{N}$ & 103 & 101 & 103 & 103 & 103 & 103 & 103 & 103 \\
\hline \multirow{3}{*}{ Q5 } & Pearson Correlation & -.130 & $-.474^{* *}$ & $-.265^{* *}$ & 1 & .154 & $.577^{* *}$ & $.420^{* *}$ & $.690^{* *}$ \\
\hline & Sig. (2-tailed) & .190 & .000 & .007 & & .121 & .000 & .000 & .000 \\
\hline & $\mathrm{N}$ & 103 & 101 & 103 & 103 & 103 & 103 & 103 & 103 \\
\hline \multirow{3}{*}{ Q7 } & Pearson Correlation & .073 & .100 & $.229^{*}$ & .154 & 1 & $.195^{*}$ & $258^{* *}$ & .163 \\
\hline & Sig. (2-tailed) & .466 & .319 & .020 & .121 & & .049 & .009 & .100 \\
\hline & $\mathrm{N}$ & 103 & 101 & 103 & 103 & 103 & 103 & 103 & 103 \\
\hline \multirow{3}{*}{ Q8 } & Pearson Correlation & .173 & $-.522^{* *}$ & .078 & $.577^{* *}$ & $.195^{*}$ & 1 & $.458^{* *}$ & $.754^{* *}$ \\
\hline & Sig. (2-tailed) & .081 & .000 & .435 & .000 & .049 & & .000 & .000 \\
\hline & $\mathrm{N}$ & 103 & 101 & 103 & 103 & 103 & 103 & 103 & 103 \\
\hline \multirow{3}{*}{ Q9 } & Pearson Correlation & -.184 & -.129 & $.208^{*}$ & $.420^{* *}$ & $.258^{* *}$ & $.458^{* *}$ & 1 & $.546^{* *}$ \\
\hline & Sig. (2-tailed) & .063 & .198 & .035 & .000 & .009 & .000 & & .000 \\
\hline & $\mathrm{N}$ & 103 & 101 & 103 & 103 & 103 & 103 & 103 & 103 \\
\hline \multirow{3}{*}{ Q10 } & Pearson Correlation & -.032 & $-.575^{* *}$ & $-.208^{*}$ & $.690^{* *}$ & .163 & $.754^{* *}$ & $.546^{* *}$ & 1 \\
\hline & Sig. (2-tailed) & .745 & .000 & .035 & .000 & .100 & .000 & .000 & \\
\hline & $\mathrm{N}$ & 103 & 101 & 103 & 103 & 103 & 103 & 103 & 103 \\
\hline
\end{tabular}

**. Correlation is significant at the 0.01 level (2-tailed).

*. Correlation is significant at the 0.05 level (2-tailed). 


\section{REFERENCES:}

Beauvais, F., \& Oetting, G. (1990). The research agenda for the next 25 years: Special issue on drug abuse, problems and solutions. New York: M. Dekker.

Berry, J.W. (2002). A Psychology of Immigration. Journal of Social Studies, 57(3), 615-640. DOI: 10.1111/00224537.00231.

Berry, J.W. (2003). Conceptual Approaches in Acculturation: Advances in theory, measurement and applied research. In K.M. Chun, P.B. Organista, \& G. Marín (Eds.), Acculturation: Advances in theory, measurement, and applied research (pp. 17-37). Washington, D.C: American Psychological Association. DOI: $10.1037 / 10472-004$.

Berry, J.W. (2006). Immigrant youth in cultural transition: Acculturation, identity, and adaptation across national contexts. Mahwah, N.J: Erlbaum.

Berry, J.W., \& Kalin, R. (January 01, 1995). Multicultural and Ethnic Attitudes in Canada: An Overview of the 1991 National Survey. Canadian Journal of Behavioural Science, 27(3), 301-320. DOI: 10.1037/0008400X.27.3.301.

Bourhis, R.Y. (1994). Ethnic and language attitudes in Quebec. In J.W. Berry \& J.A. Laponce (Eds.), Ethnicity and culture in Canada: The research landscape (pp.322-360). Toronto: University of Toronto Press.

Gordon, M.M. (1964). Assimilation in American life: The role of race, religion, and national origins. New York: Oxford University Press.

Gordon, M.M. (1971). The nature of assimilation and the theory of the melting pot. In E.P. Hollander \& R.G. Hunt (Eds.), Current perspectives in social psychology: Readings with commentary (pp. 102-114). New York: Oxford University Press.

Iceland, J., \& Nelson, K.A. (2010). The residential segregation of mixed-nativity married couples. Demography, 47(4), 869-893. DOI: 10.1007/BF03213731.

Ko, H., Roberts, M.S., \& Cho, C.-H. (September 01, 2006). Cross-Cultural Differences in Motivations and Per- ceived Interactivity: A Comparative Study of American and Korean Internet Users. Journal of Current Issues \& Research in Advertising, 28(2), 93-104. DOI: 10.1080/10641734.2006.10505201.

Lee, I., Choi, B., Kim, J., \& Hong, S.-J. (July 01, 2007). Culture-Technology Fit: Effects of Cultural Characteristics on the Post-Adoption Beliefs of Mobile Internet Users. International Journal of Electronic Commerce, 11(4), 11-51. DOI: 10.2753/JEC1086-4415110401.

Lee, S.-M., \& Ungson, G.R. (July 01, 2008). Towards a theory of synchronous technological assimilation: The case of Korea's Internet economy. Journal of World Business, 43(3), 274-289.

Ortega, M. (March 02, 2010). Multiplicity, Inbetweeness, and the Question of Assimilation. The Southern Journal of Philosophy, 46(S1), 65-80. DOI: 10.1111/j.20416962.2008.tb00154.x.

Padilla, A.M. (1980). Acculturation, theory, models, and some new findings. Boulder, Colo: Westview Press.

Padilla, A.M., \& Berry J.W. (1980). Acculturation as varieties of adaptation. In A. Padilla (Eds.), Acculturation: Theory, models and some new findings (pp. 9-25). Boulder, Colo: Westview Press.

Ramirez, M. (1984). Assessing and understanding biculturalism-multiculturalism in Mexican-American adults. In J. L. Martinez R. H. Mendoza (Eds.), Chicano psychology (pp. 77-94). Orlando, Fl: Academic Press.

Terrazas, A. (2010). Haitian Immigrants in the United States. Retrieved March 16, 2011, from www.migrationinformation.org/USfocus/display.cfm?id=770

Valencia, E.Y., \& Johnson, V. (January 01, 2008). Acculturation Among Latino Youth and the Risk for Substance Use: Issues of Definition and Measurement. Journal of Drug Issues, 38(1), 37-68. DOI: 10.1177/00220426080 3800103.

Williams, J.A., \& Ortega, S.T. (1990). Dimensions of ethnic assimilation: An empirical appraisal of Gordon's typology. Retrieved Jun 2, 2013, from http://ezproxylocal.library.nova.edu/login?url=http://search.proquest.com/ docview/57859482? accountid $=6579$ 


\section{PROUČAVANJE ASIMILACIJE IMIGRANATA SA HAITIJA NA ZAPADNJAČKU PRAKSU KORIŠĆENJA TELEFONSKIH I INTERNET TEHNOLOGIJA}

\section{Rezime:}

Studija ispituje odnose između korišćenja tehnologije u održavanju veza i očuvanja kulture zemlje porekla tokom prilagođavanja i integrisanja u kulturu zemlje domaćina.

Kroz upitnik autori istražuju na koji način se imigranti iz Haitija (koji žive u Južnoj Floridi sa različitim nivoima kontakata sa svojom zemljom) uključuju u društveni život zemlje u koju dolaze, istražujući sve važnije iskustvo savremenih migranata u svetu.

Imigracija se sastoji od individualnih iskustava uključivanja u društvo i formiranja savremenog multinacionalnog društva, gde i imigranti i građani zemlje domaćina žive u zajednici u pozitivnom okruženju. U ovoj studiji, izveštava se o početnim zaključcima i suštini problema na osnovu ankete sprovedene među imigranatima iz Haitija u oblasti Južne Floride, istovremeno istraživajući odnose obima elektronske komunikacije i nivoa integrisanja u glavne tokove kulture SAD. Brojna istraživanja su posvećena razumevanju imigracije, uključivanju i adaptaciji odraslih, ali je mnogo manje radova posvećeno tom fenomenu u Haićanskoj populaciji u vezi sa korišćenjem tehnologije u održavanju veza sa familijama u inostranstvu dok se istovremeno u potpunosti adaptiraju na zemlju domaćina, zadržavajući oba identiteta. Drugim rečima do koje mere, Haićani koji žele da imaju kontakte sa Američkom kulturom, dok u isto veme zadržavaju njihove kulturne karakteristike, čine to koristeći Internet i ostale načine savremene elektronske komunikacije.

Cilj ove studije je da istraži korelaciju između procesa integracije u kulturu i stepen korišćenja interneta kao i telefonskih komunikacionih veza među Haićaima koji žive u Južnoj Floridi. Internet i telefon su potreba koji postaju glavno oruđe kako bi čovek upoznao okruženje, za održavanje već postojećih kontakata ali isto tako i za organizaciju sopstvenog života. Ovo se posebno odnosi na imigrante koji se često oslanjaju na nove i stare društvene mreže kako bi se prilagodili zemlji u koju dolaze. Ova studija istražuje pet dobro poznatih mera odnosno indikatora procesa akulturacije a to su poznavanje jezika, korišćenje jezika, dužina boravka u zemlji u koju dolaze, starost i kontakti sa sličnim društvenim grupama. Ovde se takođe istražuju prednosti korišćenja interneta i sličnih programa, kako bi se kontaktirali prijatelji i rođaci kako na Haitiju tako i u Americi putem e-mail-a, tekstualnih poruka i društvenih mreža.

U našoj studiji, imigranti sa Haitija koji se smatraju visoko integrisanim ljudima su mlađi ljudi, oni koji tu žive duže vreme, koji dobro poznaju i kreolski i engleski jezik, koji govore sa prijateljima i rođacima na oba jezika i koji provode svoje slobodno vreme kako sa amerikancima tako sa drugim Haićanima.

\section{Ključne reči:}

kulturna integracija, imigrant, komunikacijske tehnologije, internet, telefonske tehnologije, korelacija.

Received: July 17th, 2013.

Correction: August 22nd, 2013.

Accepted: September 2nd, 2013. 